\title{
ESOPHAGEAL MUCOSAL RESECTION VERSUS ESOPHAGECTOMY: A COMPARATIVE STUDY OF SURGICAL RESULTS IN PATIENTS WITH ADVANCED MEGAESOPHAGUS
}

\author{
Mucosectomia esofágica versus esofagectomia: estudo comparativo dos resultados cirúrgicos imediatos e tardios em pacientes \\ operados por megaesôfago avançado
}

Gustavo Carvalho de OLIVEIRA, Rodrigo Lima Bastos da ROCHA, João de Souza COELHO-NETO, Valdir TERCIOTTI-JUNIOR, Luiz Roberto LOPES, Nelson Adami ANDREOLLO

From the Disciplina de Moléstias do Aparelho Digestivo, Departamento de Cirurgia, Faculdade de Ciências Médicas, Universidade Estadual de Campinas UNICAMP (Diseases of Digestive System Discipline, Department of Surgery, Health Sciences Faculty, State University of Campinas - UNICAMP), Campinas, SP, Brazil

HEADINGS - Esophageal achalasia. Chagas disease. Esophageal motility disorders. Esophagectomy.
ABSTRACT - Background: The surgical treatment of advanced megaesophagus has no consensus, being esophagectomy the more commonly used method. Since it has high morbimortality - inconvenient for benign disease -, in recent years an alternative has been introduced: the esophageal mucosal resection. Aim: To compare early and late results of the two techniques evaluating the operative time, length of ICU stay; postoperative hospitalization; total hospitalization; intra- and postoperative complication rates; mortality; and long-term results. Methods: Were evaluated retrospectively 40 charts, 23 esophagectomies and 17 mucosectomies. In assessing postoperative results, interviews were conducted by using a specific questionnaire. Results: Comparing the means of esophagectomy and mucosal resection, respectively, the data were: 1 ) surgical time - $310.2 \mathrm{~min}$ and $279.7 \mathrm{~min}$ ( $p>$ $0.05)$; 2 ) length of stay in ICU -5 days and 2.53 days $(p<0.05) ; 3$ ) total time of hospitalization -24.25 days and 20.76 days $(p>0.05)$; 4 ) length of hospital stay after surgery - 19.05 days and 14.94 days $(p>0.05) ; 5)$ presence of intraoperative complications - 65\% and $18 \%(p<0.05) ; 6)$ the presence of postoperative complications $-65 \%$ and $35 \%$ ( $p>0.05$ ). In the assessment of late postoperative score (range $0-10)$ esophagectomy $(n=5)$ obtained 8.8 points and 8.8 points also got mucosal resection $(n$ $=5$ ). Conclusions: Esophageal mucosal resection proved to be good alternative for surgical treatment of megaesophagus. It was advantageous in the immediate postoperative period by presenting a lower average time in operation, the total hospitalization, ICU staying and complications rate. In the late postoperative period, the result was excellent and good in both operations.

\author{
Correspondence: \\ Luiz Roberto Lopes \\ lopesIr@terra.com.br \\ Financial source: Fundação de Amparo à \\ Pesquisa do Estado de São Paulo (FAPESP), \\ processo $n^{\circ} 08 / 54101-4$ \\ Conflicts of interest: none
}

Received for publication: 12/08/2014 Accepted for publication: 25/11/2014

DESCRITORES - Acalásia esofágica. Doença de Chagas. Transtornos da motilidade esofágica. Esofagectomia.
RESUMO - Racional: O tratamento cirúrgico do megaesôfago avançado não é consensual sendo mais comumente usada a esofagectomia. Por tratar-se de técnica que apresenta maior morbimortalidade e empregada em doença benigna, foi introduzida nos últimos anos, como alternativa, a mucosectomia esofágica. Objetivo: Comparar os resultados imediatos e tardios das duas técnicas avaliando-se os tempos operatório, de internação em UTI, de internação do pós-operatório, de internação total; taxas de complicações intra-operatórias e pós-operatórias; taxa de mortalidade; e resultados a longo prazo. Métodos: Foram avaliados 40 prontuários, retrospectivamente, sendo 23 esofagectomias e 17 mucosectomias. Na avaliação dos resultados pós-operatórios, foram realizadas entrevistas, mediante uso de questionário específico. Resultados: Comparando-se as médias da esofagectomia e mucosectomia, respectivamente, os dados foram: 1) tempo cirúrgico - 310,2 min e 279,7 min ( $p>0,05)$; 2) tempo de internação em UTI - 5 dias e 2,53 dias $(p<0,05)$; 3 ) tempo de internação total - 24,25 dias e 20,76 dias ( $p>0,05)$; 4 ) tempo de internação após a operação - 19,05 dias e 14,94 dias ( $p>0,05)$; 5) presença de complicações intra-operatórias - $65 \%$ e $18 \%(p<0,05)$; 6$)$ presença de complicações pós-operatórias imediatas - $65 \%$ e $35 \%$ ( $p>0,05)$. Na avaliação do escore pós-operatório tardio (escala $0-10)$ a esofagectomia $(n=5)$ obteve 8,8 pontos e também 8,8 pontos obteve a mucosectomia $(n=5)$. Conclusões: A mucosectomia esofágica mostrou-se boa alternativa no tratamento cirúrgico do megaesôfago avançado. Foi vantajosa no pós-operatório imediato por apresentar menor média de tempo na operação, na internação total, na UT e no índice de complicações. No pós-operatório tardio, o resultado foi excelente e bom nas duas operações.

INTRODUCTION

A merican trypanosomiasis described by Carlos Chagas in 1909 today is still a socioeconomic problem at regional and national level, mainly afflicting the countries of the Southern Cone of America.

According to the World Bank ("World Development Report", 1993), the impact of Chagas disease relative to other endemic transmissible diseases in Latin America, measured in "years of disability-adjusted life", was only surpassed by the time set of diarrheal diseases, respiratory and AIDS; so, it is important public health problem.

Megaesophagus is one of the clinical presentation of Chagas' disease. It is estimated that at least $4 \%$ of chagasic patients present megaesophagus (about 300,000 patients) $)^{8}$. On it, there is destruction of intramural nerve plexus of the esophagus, reduced peristalsis at the level of body of the organ and failure at the opening of the lower sphincter (achalasia) on swallowing. Thus, there is incoordination and dilation, reducing its contraction capacity. Are admitted other causes for achalasia, in these cases, calling it idiopathic achalasia of the esophagus ${ }^{1,10,11,13,14,15}$.

Dysphagia is the manifestation that leads the patient to seek medical advice, and is generally progressive ${ }^{12,14}$. Megaesophagus is classified according to the transverse 
diameter of its body, ranging from 1 to 4 (Mascarenhas' score). The treatment is surgical and this classification assists the choice of surgery ${ }^{8,12,14}$

In cases of megaesophagus grade 4 - also called advanced form -, the preferred surgery technique is the subtotal esophagectomy, using the stomach for reconstruction of the alimentary tract. Another proposal for the treatment of advanced megaesophagus is the Serra-Doria's surgery, which consists of a cardioplasty and a partial gastrectomy, rebuilding the alimentary tract in Roux-en-Y.

Good results were obtained with this procedure in patients undergoing reoperation for achalasia ( 15 cases of a non advanced form and five in an advanced form by Ponciano et al. ${ }^{16}$ in 2004.In the early 90s Aquino et al. ${ }^{3,4,5,6}$, following preliminary studies in dogs and later in cadavers to verify its feasibility began to perform a new therapeutic modality for advanced megaesophagus: esophageal mucosectomy. It is a method which withdraw the mucosa and submucosa of the esophagus, through its complete invagination through via cervico-abdominal combined without thoracotomy and conserving the entire muscular layer. Thereby is accomplished the removal of preneoplasic mucosal lesions and avoiding the complications of dissection and detachment of the esophagus in mediastinum.

The team of the Digestive System Diseases Service at the Clinic Hospital of Unicamp, in about 15 years, has treated some cases of megaesophagus with esophageal mucosectomy ${ }^{12,14}$. However, subtotal esophagectomy has not been abandoned and their results have not yet been directly compared to the esophageal mucosectomy.

The aim of this study was to compare the surgical results of the two methods used in the treatment of advanced megaesophagus in the last 15 years. The parameters used took into account immediate and late surgical results.

\section{METHODS}

This study was approved by the Ethics Committee in Research of the Faculty of Medical Sciences, State University of Campinas - Opinion No. 323/2008.

Was conducted a retrospective review of medical records of patients with megaesophagus forming a study group of 40 patients, 23 underwent esophagectomy and 17 esophageal mucosectomy.

The observed data were: operative time, length of stay in the intensive care unit and hospital postoperative total staying, rate of SIRS - systemic inflammatory response syndrome -, infection, blood transfusion, pulmonary complications (hemothorax, pleural injury, empyema, pneumonia), lesions of the thoracic duct, abdominal complications and esophagogastric anastomosis complications.

As for the evaluation of the postoperative period in clinical interviews, was used a score already applied previously by Aquino et al. ${ }^{4}$ in 2007 . This scoring system and its score included: 1 ) quality of swallowing (normal=2 points; occasional dysphagia $=1$ point; frequent dysphagia $=0$ point); 2) occurrence of gastroesophageal regurgitation both postprandial and at recumbency (missing $=2$ points; occasional=1 point, frequent $=1$ point); 3 ) change on bowel habit (unchanged=2 points; occasional diarrhea or constipation $=1$ point; frequent diarrhea or constipation $=0$ point); 4) weight gain (increased $=2$ points; unchanged $=1$ point, decreased $=0$ point); 5 ) satisfaction with the intervention (satisfied $=1$ point, dissatisfied $=0$ point); 6 ) returning to occupational activities (yes $=1$ point; no $=0$ ).

In respect to Resolution 196/96, which provides for the Guidelines and Standards for Research Involving Human Subjects of the National Health Council, all patients interviewed were informed of the objectives of the study that there was no physical or mental risk to provide these few data to researchers, without any form of identification of respondents.

The statistical methods used to test the data collected were the chi-square test (comparing presence of complications) and Student's t test in comparison with the average maximum permissible error of $5 \%$.

\section{RESULTS}

Data evaluation and percentage comparisons showed no significant differences between men and women, nor their average age, and then grouped together.

Intraoperative complications occurred in 15 esophagectomies (65\%) and three mucosectomies (18\%). In esophagectomies major complications were pleural (injury and stroke) which occurred in 12 surgeries (52\%). The following, pneumothorax occurred in four patients (17\%), probable injury of recurrent laryngeal nerve in two surgeries (9\%) and lesions in the thoracic duct in other two (9\%).

In mucosectomies, there were three types of intraoperative complications, present in each surgery: probable recurrent laryngeal nerve injury, injury to liver capsule and splenic trauma.

The chi-square test applied between the two modalities and complications had a score of 8,937 . For a significance level of $p=0.002$ and a degree of freedom, the expected value for the independent variables was up to 3,841 . Thus, the result indicates that there is a relationship between surgical procedures and complications. Therefore, the esophageal mucosectomy is significantly the surgical procedure with lower risks of intraoperative complications (Figure 1).

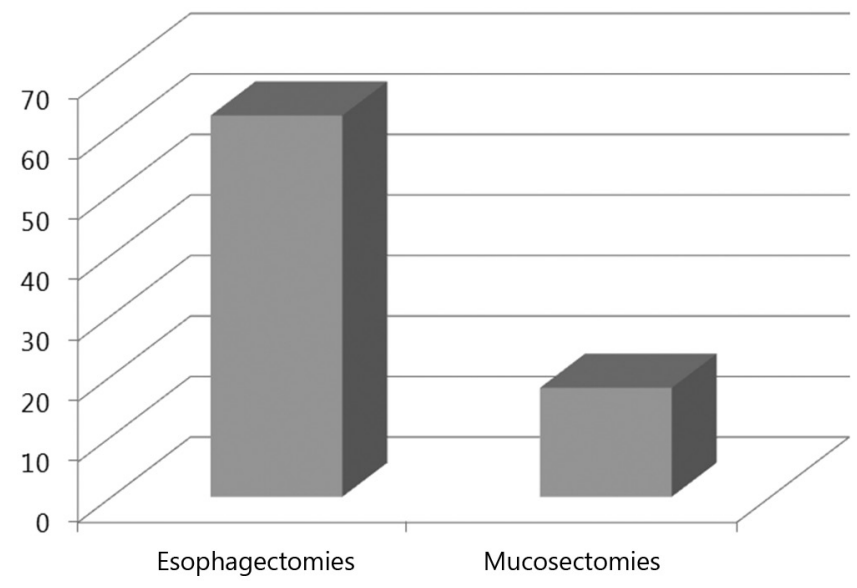

FIGURE 1 - Intraoperative complications in \% $(n=40)$

Regarding postoperative complications, they occurred in 15 esophagectomies (65\%) and six mucosectomies (35\%). In esophagectomies, there were four cases of cervical anastomotic fistula (17\%), three of these with esophagogastric anastomotic stricture (13\%), three bacteremia (13\%) and in two (9\%) sepsis, two lymphatic fistula (9\%), and isolated cases of severe respiratory failure, pleural empyema and mediastinal abscess. In mucosectomies, there were five cases of cervical fistula (29\%), and one evolved in the late postoperative period with stenosis. There were also isolated cases of abdominal abscess, pleural effusion and lung abscess mediastinal (Figure 2). The chi-square test, when comparing the postoperative complications between the two techniques, was 3.509 with a $p=0.06$. Thus, the values founded were not enough to say that there are significant differences between surgeries with regard to the prevalence of postoperative complications, with a $\mathrm{p}$-value threshold to the admission $(<0.05)$. 


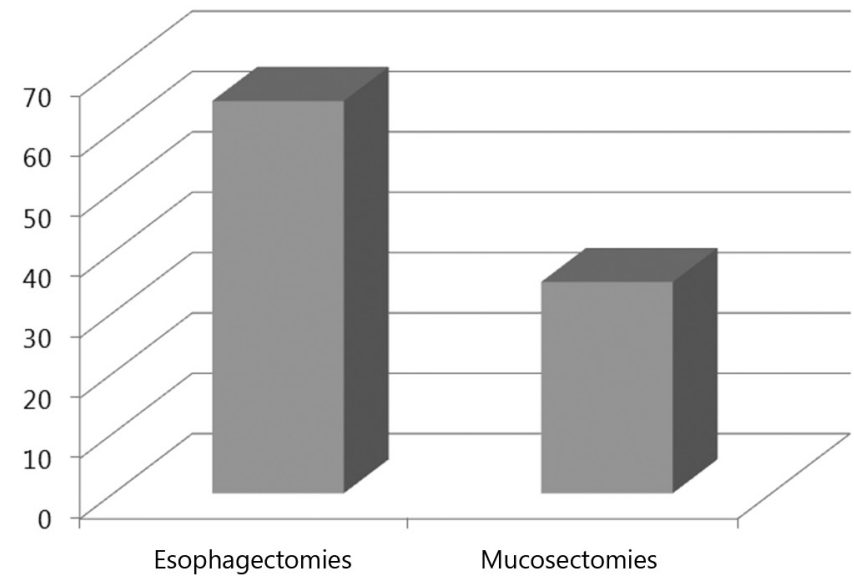

FIGURE 2 - Postoperative complications in $\%(n=40)$

There were no deaths in surgeries.

Taking into account the average surgical time, average length of stay in ICU, mean time of hospitalization and length of hospital stay after the operation, the registry records of these aspects allowed evaluation in 33 operations (12 mucosectomies and 21 esophagectomies) and were: 1) mean surgical time: esophagectomy $310.2 \mathrm{~min}$ and mucosal resection $279.7 \mathrm{~min}$ (total $\mathrm{n}=37$ and $\mathrm{p}=0.149$, not significant, Figure 3$) ; 2$ ) average length of stay in ICU: esophagectomy 5 days and mucosal resection 2.53 days (total $n=33$ and $p=0.046$, with statistically significant difference, Figure 4); 3) mean time of hospitalization: esophagectomy 24.25 days and mucosal resection 20.76 days (total $n=33, p=0.119$ not significant, Figure 5); 4) mean hospital stay after the operation: esophagectomy 19.05 days and mucosal resection 14.94 days (total $n=33, p=0.144$ not statistically significant, Figure 6).

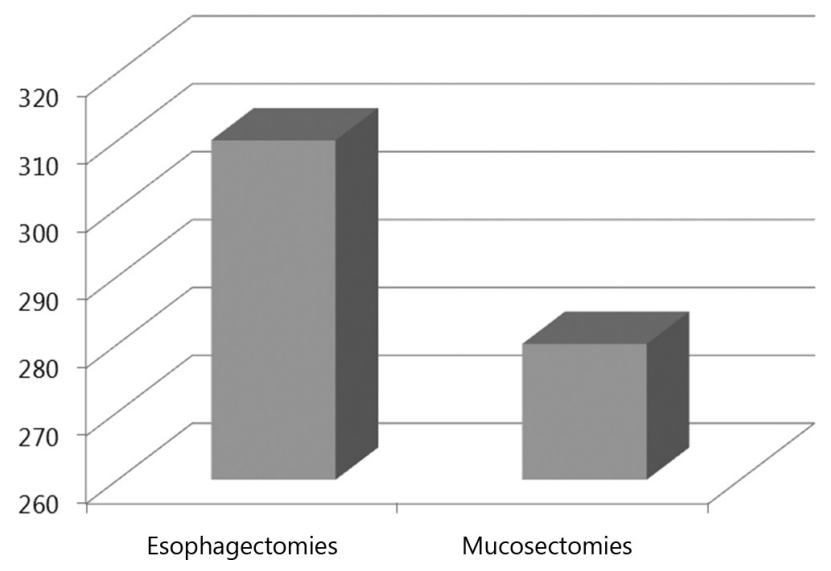

FIGURE 3 - Mean surgical time $(n=40)$

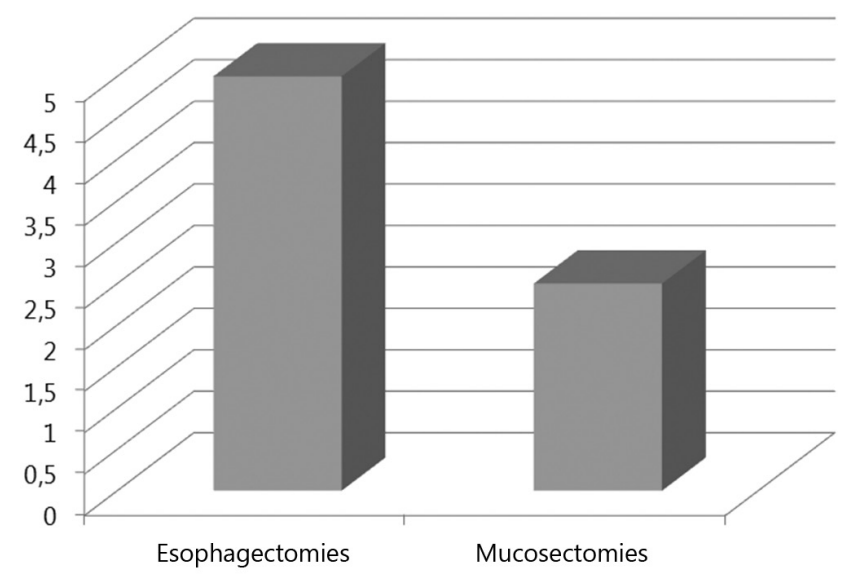

FIGURE 4 - Average length of stay in ICU in days $(n=40)$



FIGURE 5 - Mean total hospitalization time in days $(n=40)$

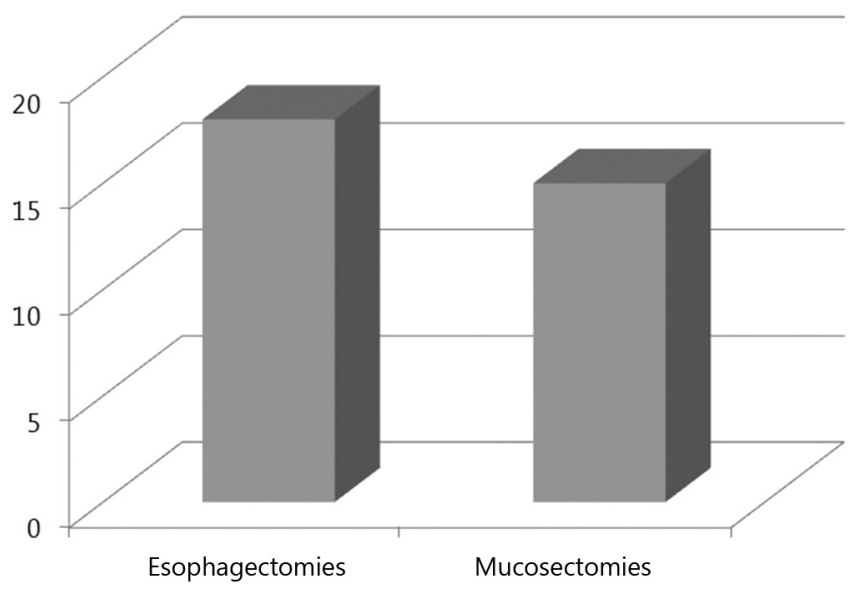

FIGURE 6 - Average length of hospital stay after surgery in days $(n=40)$

In the postoperative evaluation with at least one year of follow up (mean 5.36 years), ten patients were interviewed, yielding excellent scores, averaging 8.8 points (maximum of ten points) in esophagectomy $(n=5)$ and 8.8 points in mucosectomy $(n=5)$, showing up late excellent surgical outcome.

\section{DISCUSSION}

The comparison of the two surgical modalities in the treatment of advanced megaesophagus demonstrated that mucosectomy has better results compared to esophagectomy, with fewer complications, shorter surgical time and lower total hospitalization in ICU and after the procedure, and the intraoperative operative time and length of ICU stay significantly relevant. To assess whether a larger sample than used $(n=33$ and $n=37)$ in items averaging time would be statistically significant, was done the simple experiment of bending samples, making up a duplicate of all values, reaching up hypothetical values $n=66$ and $n=74$ operations. With these numbers, the items before without statistical significance, began to have a $p<0.05$ threshold or 0.06 , when redone the Student $t$ test. This makes us believe that with a larger number of surgeries, esophageal mucosectomy is statistically better than esophagectomy in all items evaluated in this paper.

Other studies have shown lower rates of complications usually found in the esophagectomies. Aquino et al. ${ }^{2,4}$ have shown good results with mucosectomy. In 60 surgeries evaluated, $18.3 \%$ of complications were reported, and two deaths (3.3\%). The kind of complication most often found in mucosectomies were complications with the esophagogastric 
anastomosis, occurring in five cases, $29 \%$, even more than in esophagectomies (four cases, 17\%), however, with $p>0.05$. This anastomosis presents difficulties to be done in both surgical modalities, although there is no statistically significant difference between the results in both techniques. But, there is a slight tendency that the non-removal of the esophagus is related to percentage of fistulae slightly bigger and on certain cases, followed by stenosis.

However, as already shown, the post-surgical outcome is similar in both surgeries. Late evaluation of mucosectomies also was evaluated by Aquino et al. 2,4,6 and even cervical anastomosis has been compared in relation to a technique of mechanical or manual suture; also without statistical significance, the mechanical technique had lower dehiscence of anastomosis ( $20 \%$ compared with $33 \%$ for a total of 30 patients evaluated). In late evaluation itself, the results were great too, with $92 \%$ of patients reporting significant improvement in symptoms similar to what was described in the present study².

The esophagectomies had a significantly higher rate of surgical complications, as previously demonstrated in the results, as well as higher average surgical time, total hospitalization days in ICU and after surgery. The most frequent complications were pleural (injuries and effusion), occurring in $52 \%$ of surgeries. The longer time of surgery due to higher thoracoabdominal handling to its realization explains the high rate of complications when compared to esophageal mucosectomy. However, the post-surgical time, despite greater hospitalization, is satisfactory and as good as the mucosectomy, as already shown.

Tomashich et al. ${ }^{18}$ presented postoperative complications of $39.3 \%$ and mortality rate of $13.7 \%$. Braghetto et al. ${ }^{7}$ obtained $33.3 \%$ of early postoperative complications and $22 \%$ of late complications. Tinoco et al. ${ }^{17}$ evaluating esophagectomies, obtained the mean hospital stay of 6.9 days, 30-day mortality of $5.6 \%$ and 11 cases of pleural lesions in 64 surgeries. Also in this study, the authors have evaluated the incidence of cervical fistulae, which was $14 \%$, showing that the esophagogastric anastomosis complications have different percentage among different medical services.

Crema et al. ${ }^{9}$ demonstrated excellent surgical results in the treatment of 60 cases of megaesophagus by laparoscopic esophagectomy ${ }^{22}$. The average duration of surgery in this study was $160 \mathrm{~min}$, there was no mortality and a total of $20 \%$ of complications, the most frequent being hemopneumothorax, dysphonia and cervical fistulae. Aquino et al. ${ }^{3}$ evaluated the treatment of recurrent achalasia, by various techniques, resulting in esophagectomy a morbidity rate of $50 \%(n=4)$ and two deaths (25\%). Compared with mucosectomy, the results were inferior in this study.

As understood, esophagectomy is a surgery with a level of morbidity usually greater than $20 \%$, and in some cases, death. Alternatives have recently been tried as esophageal mucosectomy and laparoscopic esophagectomy. The results have been better, although the treatment of advanced megaesophagus is not always consensual. The final result, when clinically evaluated the patient, looks pretty good both in esophagectomy and in mucosectomy. The great advantages for the patient and the health service are fewer complications, shorter operative time and lower times in ICU and total hospitalization. The use of this technique requires good training and in some patients, it proved difficult to perform, especially if there were previous surgery and/or many adhesions.

Esophageal mucosectomy proved advantageous with respect to the immediate postoperative period, with lower average surgical time, total hospitalization days in ICU and after surgery and fewer complications. The intraoperative complications and length of ICU stay were significantly lower $(p<0.05)$. In the late postoperative period, the result was very good in both surgeries.
CONCLUSION

Esophageal mucosal resection proved to be good alternative for surgical treatment of megaesophagus. It was advantageous in the immediate postoperative period by presenting a lower average time in operation, the total hospitalization, ICU staying and complications rate. In the late postoperative period, the result was excellent and good in both operations.

\section{REFERENCES}

1. Andreollo NA, Lopes LR, Brandalise NA, Leonardi LS. Acalasia idiopática do esôfago: análise de 25 casos. GED. 1996; 15: 151-155.

2. Aquino JLB, Neto JAR, Muraro CLPM, Camargo JGT. Mucosectomia esofágica no tratamento do megaesôfago avançado: análise de 60 casos. Rev Col Bras Cir. 2000; 27:109-116.

3. Aquino JLB, Said M, Pereira EVA, Vernaschi B, Oliveira MB. Tratamento cirúrgico do megaesôfago recidivado. Rev. Col. Bras. Cir. 2007;34:310-313.

4. AquinoJLB,SaidMM, FernandesPR.Avaliaçãotardiadamucosectomia esofágica com conservação da túnica muscular em pacientes com megaesôfago avançado. Rev Col Bras Cir 2007; 34: 9-15.

5. Aquino JLB, Said MM, Maziero D, Pliveira JMP, Leando-Merhi VA Reconstrução esofágica pela esofagocoloplastia no megaesôfago avançado em pacientes gastrectomizados. ABCD Arq Bras Cir Dig 2009;22(4):197-200

6. Aquino JLB. Avaliação da anastomose esofagogástrica cervical com sutura mecânica em pacientes com megaesôfago avançado. Rev. Col. Bras. Cir. 2005, vol. 32, no. 3, pp. 143-146.

7. BraghettoIM, Gonzalo $\mathrm{CH}$, Patricio BP, Korn B, RamirezC. Esofagectomía porcirugíamini-invasivavíatoracoscópicaolaparoscópica:indicaciones y resultados. Rev Chil Cir. 2005; 57: 118-126.

8. Ceneviva R, Ferreira-Santos, R, Santos JS, Mente ED, Sankarankutty AK. Alterações cronológicas do perfil dos pacientes e da modalidade de tratamento cirúrgico do megaesôfago chagásico. Acta Cir Bras 2002; 17: 125-128.

9. Crema E, Ribeiro LBP, Sousa RC, Terra Júnior JA, Silva BF, Silva AA, et al. Esofagectomia transhiatal laparoscópica para o tratamento do megaesôfago avançado: análise de 60 casos. Rev. Col. Bras. Cir. 2009; 36: 118-122

10. Dantas RO. Comparação entre acalásia idiopática e acalásia conseqüente à doença de Chagas: revisão. Arq Gastroenterol. 2003;.40: 126-130.

11. Herbella FAM, Oliveira DRCF, Del Grande JC. Are idiopathic and chagasic achalasia two different Diseases? Dig Dis Sci. 2004; 49: 353-360.

12. Oliveira GC, Lopes LR, Andreollo NA, Braga NS, Coelho Neto, JS. Tratamento cirúrgico do megaesôfago no Hospital de Clínicas da UNICAMP - fatores associados a melhores ou a piores resultados. Rev Col Bras Cir. 2009; 36: 300-306.

13. Oliveira GC, Lopes LR, Coelho-Neto JS. Acalásia idiopática do esôfago: análise da história clínica e antecedentes na etiologia e perfil dos pacientes. ABCD Arq Bras Cir Dig. 2010;23(1):11-15

14. Oliveira GC, Lopes LR., Andreollo NA, Coelho Neto JS. O megaesôfago tratadocirurgicamente:perfilepidemiológicodospacientesoperados no Hospital de Clínicas da Universidade Estadual de Campinas entre 1989 e 2005. Rev Soc Bras Med Trop. 2008; 41: 183-188.

15. Park W, Vaezi MF. Etiology and pathogenesis of achalasia: the current understanding. American Journal of Gastroenterology. 2005; 100:1404-1414.

16. Ponciano H, CecconelloI, Alves L, Ferreira BD, Gama-RodriguesJ.Cardioplastia e gastrectomia parcial em Y-de-Roux (operação de Serra-Dória) para reoperações no megaesôfago. Arq Gastroenterol. 2004; 41: 155-161.

17. Tinoco RC, Tinoco AC, El-Kadre LJ, Rios RA, Sueth DM, Pena FM Esofagectomia laparocópica transhiatal: resultados imediatos. Arq Gastroenterol. 2007; 44: 141-144.

18. Tomasich FDS, Valladares GCG, Demarchi VCA, Augusto VC, Gagliardi D. Complicações e letalidade hospitalar da esofagectomia com linfadenectomia em dois campos: estudo de 132 casos. Acta Oncol Bras. 2003; 23: 375-387. 